\title{
THE ARCHAIC ELEMENTS OF THE KYRGYZ NATIONAL GAMES
}

\author{
Mehmet Türkmen ${ }^{\mathrm{i}}$ \\ Prof. Dr. \\ Muş Alparslan University, \\ Muş, Turkey \\ \& \\ Kyrgyz-Turkish Manas University, \\ Bishkek, Kyrgyzstan \\ orcid.org/0000-0002-5926-7522
}

\begin{abstract}
:
Physical culture and sport as a product of certain historical conditions for the development of society, it is the sum of the historical results of human spiritual activity. In this study, is presented one of the oldest Turkish peoples and the background of the traditional sports of the Kyrgyz with a long history. Steppe is compatible with nomadic lifestyle, national will and according to qualifications horse riding, were many sports, including shooting and wrestling. Purpose of the research: natural conditions that reveal traditional sports, the factors that determine the practical character of sports, what are the pedagogical and socio-cultural benefits of the Kyrgyz people? Method of research; it is possible to examine with a few methods, but it is preferred to use the historical method. The limitation of the study: present Kyrgyzstan and their historical geographies. As a result, Kyrgyz, which is understood to be both intellectual and moral as well as physical, has taken part in all stages of traditional sports, social structure and life. There have been some add-ons and outputs according to the changes and developments of the era. The economic life is based on animal husbandry and becoming nomadic people, they live in steep natural conditions and climatic conditions, very frequent battles in the old world, etc., it has determined the style and demand of these sports. In practice, the Kyrgyz population have overcome all these difficulties and became strong military people.
\end{abstract}

Keywords: Kyrgyz national games, historical background

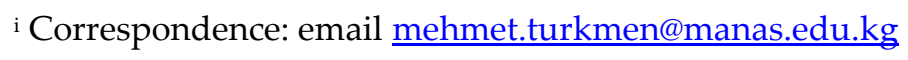




\section{Introduction}

The Kyrgyz living in the geographic areas where the ancient Turkish nomadic steppe culture was formed and developed today, determining the nomads and settlements, economic and social life areas, accordingly, are also the most able to preserve the characteristics of the first Turkish peoples. In addition to these, the Kyrgyz have the most potential knowledge and experience among the Turkic peoples in examining the origin of the sports in question, in their theoretical and practical examination, in bringing to light the forgotten ones and the ones which are about to be forgotten, and reflecting the unknown aspects with their original names (Türkmen, 2013, 74). Sport's history probably goes as far as humans existed as active beings. Sports are a useful way for people to increase their mastery of nature and the environment. Physical activities give people social position and status. It can create change in behavior. It was always like this throughout history. Especially in the Turks, the culture of sports and games was very common. This continued by developing from the Assyrians, Etiler and Hittites, namely the front Asian civilizations. There is a controversy about the origins or emerging of some sports. Some sports and practices survived to the present day. For example, pulling rope is practiced as traditional sports in Turkey today. The position of sports affected other societies as well. For example, it is seen that the Turks had an influence on the art of the Etruscans. Every nation has an understanding of sports culture that comes from the past, originates from social structure and life, and partially includes geographical features (Türkmen et al., 2006). Sportive activities have many benefits such as entertaining people and providing them to have a good time. For example, sports make people's bodies look beautiful and aesthetic. It is accepted by many educators that sports play a role in the formation of personality and the development of character traits. Sports, as a phenomenon that exhibits extensive group lives as well as intense interpersonal relationships, have both a social quality and is considered a social need. Sports are directly under the culture or the cultural structure elements that it creates in different forms and contents in each society. Cultural characteristics and behaviors vary from society to society. The information, thoughts and practices in Asian body culture are implemented in different ways from time to time, rather in parallel with the cultural lives of societies The culture created by the mystical understanding of life, war difficulties and philosophical world views in Asian societies made sports a tool for the balance of body and soul in that society and brought up the idea of its widespread usage in the society The popularization of sports in the society, along with many other factors, seems to be related to the value judgments, traditions and customs that guide individuals and support sports types (Türkmen \& Ziyagil, 2020).

Physical culture and sports, as a product of certain historical conditions for the development of society, constitute the sum total of the historically occurring consequences of man's spiritual activity. In the conditions of the nomadic lifestyle, equestrian sports and games remained the main forms of physical culture and the main means of physical education, and among children - again reflecting their content, outdoor games are products of a nomadic lifestyle. Scientists continue to study history and culture 
in Kyrgyzstan. There is also great interest in the history of physical culture. Efforts are being made to preserve and restore the various traditions, rituals and spiritual values of the national culture. The main component of any national image was physical exercises and games. Strength, dexterity and distance competitions were used not only as festival entertainment, but also as a test of people's physical and moral strength and spirit. It was an expression of flexibility, determination and healthy spirit (Mendot ve ark., 2014).

A shining feature of every nation's culture is the games it creates. Game is the emblem of a culture, so deep knowledge of game-based practices is an important element in getting to know a society (Parlebas, 2005; Lavega, 2007). For centuries these games have been present in the daily lives of children and adults. They develop special mental characteristics and important personal qualities, and reflect the social structure of the nation's worldviews. Therefore, one of the most important issues at the moment is the revival of Kyrgyz folk culture. In order for a nation to be protected as a nation, it is necessary to examine the history and culture of the nation in depth. The formation and development of physical culture and sports is closely related to the historical stages of the development of the Kyrgyz, their common history and the culture of other Turks along with their history. Physical culture is one of the historically formed parts of national culture and is also one of the most important tools for educating a person. As a result, the development of human culture, including physical culture as part of the general culture of the people, became an important business throughout Kyrgyzstan.

As a continuation of the nomadic period, Kyrgyz ceremonies and entertainment, the supply of game meat was preserved with all its organization in the Islamic period. For example, the continuation of hunting in the Seljuks as a ritual, a military sports and maneuver, and the rulers' organization of public feasts and entertainment after hunting ceremonies were nothing more than the passing of the religious rites of the ancient Turks to the Islamic era by losing their religious nature. In fact, these hunting ceremonies had a religious identity when the Turks were in the totem period. The hunts that the ancient Turks were most careful about were religious hunts. Ancient Turks were also hunted for religious and economic purposes. Since the Kyrgyz did not have much to do in the long winters, they used to hunt. In the Kyrgyz, who did not deal with other business than animal husbandry and cultivation, hunting was done as entertainment. Mountain goats, wild boars, lynx, hyenas and tigers were hunted in the south. Hunting was carried out with birds and dogs as blood sports on horses. The observation of the same order in Turkish cultural life since the Gokturks strongly confirms the place of the Kyrgyz culture in the Turkish culture environment. Sports historiography emerged as a sub-discipline in the Western world since the first quarter of the 20th century. This situation gave very important clues in understanding the history of all societies. Moreover, it greatly influenced the emergence of new knowledge in transforming existing social relations. For example, German Sociologist N. Elias, the founder of the Theory on Figuration, drew attention to the direct proportion between the birth of modern sports and the civilization process and examined the relationship between them in his two-volume work titled Civilization Process. (Elias, 1939). Therefore, it would not be wrong to claim that the pioneering examples of sports historiography were produced within the framework of 
the "social history" movement that forces the hegemony of intellectual and political historiography. Even though sports historiography started in the 1930s, it developed at a level that makes all disciplines envy since the 1980s. As it is known, the thoughts and behaviors, languages, values and habits of societies ensured the formation of a common culture and gave them a national identity. In his struggle with nature, some of the tools (horse, arrow, sword, bayonet etc.) he used in his fight against the enemies became the elements of his desire to have fun over time, and by taking advantage of these, they turned to various sports and games. Thanks to these games, they both defended themselves by keeping the body vigorous, prepared for war and had fun by engaging in sportive activities. These sporting activities were sometimes turned into a race, and the winner of the race was regarded as the symbol of heroism and power. They included these games in almost every phase of their social, political, religious and economic structure and life.

It was aimed to make a retroactive "historical accounting" in order to make a real "period" of traditional sports games in the Kyrgyzs, to see their form and intellectual aspects, and more importantly, to determine their place in every phase of their social structure and life. Finding the reasons for the emergence of traditional sports games of any Turkish people, including Turkey, and writing their history and cultural characteristics, without taking into account the Kyrgyz, will remain in the air, and will be as valuable as a paper written. In the meantime, especially the equestrian nomad culture, which gave its name to the Turkish sports culture, was the mobilization tool, as well as the determination, development and transfer of the Turkish sports tradition to other cultures. Academic deepening especially in traditional equestrian sports can only be achieved by analyzing and knowing Kyrgyz traditional equestrian sports games well. Because the formation and development of Kyrgyz folk dances and entertainment is closely related to the development history of the ethnic group itself. While credible studies state that Kyrgyz are among the oldest peoples of Central Asia, they explain, based on classical Chinese sources, that proto-Kyrgyz roamed the Asian steppes in 201 BC (3rd century BC) (Bartold, 1996).

\section{Purpose}

Wandering and exploring the steppe excursions, which are a link between the nomadic and advanced agricultural cultures of the West and the East, together with other nomadic tribes created, developed and enriched the vast material and spiritual culture and most importantly succeeded in bringing it to the present day. Naturally, this process could not happen without mutual influences and changes, without the processes of acculturation (borrowing another culture) and inculturation (mastering a foreign culture). Let us state that we will not claim that we will determine the entire historical background of the traditional sports games of the Kyrgyz in this study. We also think that it is necessary to distinguish between two different orientations of the history and culture of the game or sports in question. Although they cover each other, the first of these methods is objective and historical, and the second is subjective and socio-psychological. In both cases, we will 
not try to prove all of their arguments in this study, but only to explain and exemplify them as a representation.

\section{Methods}

Due to the method of the study, it is possible to examine it with several methods, but among them, it was preferred to use qualitative and historical scanning methods.

\section{Hypothesis and Universe of the Study}

However, it is reported that the Kyrgyz, who have such a vast and rich potential on the subject(s), have the most inadequate publications among the peoples of Central Asia. In fact, it is not true to say that there are few studies on the subject, at least it is obvious that there are more Turkish peoples in number (Türkmen \& Arstanbekov, 2020). However, studies that evaluate the monographic studies of Central Asian peoples on the subject find the researches of all states sufficient. They only focus on Omurzakov's Kyrgyz studies (Kyrgyz national sports and national games) and show him as an example. But from the studies of Kazakhstan, Uzbekistan, Tajikistan and Turkmenistan, they find these Kyrgyz studies "less meaningful" (Taysayev, 1997). Simakov's work provides, without any mistakes, a fine description of the games of this generalized past, without depth or sense of change, because there is not enough material to suggest any development process. He paints a historical picture of the games, systematically going through Buddhist and Shamanic rituals and carefully. However, since Rojdestvenskiy came to report to the Soviet communist party Politburo (Politiçeskoye Byuro), its historical image is partial and opaque, as most texts deal only marginally with games. They both gladly cite their sources, but do not give the principle of the secret in production, because they both disdain the culture they wrote. Thus, many deviations can be suspected of plunging into sectarian divergences, especially speaking of possible bias.

\section{Limitations of the study}

Organizations where traditional sports games were performed in the past and even today are clearly not just an opportunity to "sweat", to reveal "natural" combative instincts or to express through symbols. They are also carefully structured public organizations organized around the social values of broad moral and political resonance. The universe of the study is limited to examining the historical background of the traditional sports of the Kyrgyz Turks.

\section{Background of Kyrgyz Traditional Equestrian Sports}

\subsection{Physical culture in ancient Turks}

The practices consisted of the entire cycle of rituals carried out over several years in several stages. For example, among the peoples of Central Asia there was the first 
independent ride on horseback in three years or the first participation in horse racing in seven years. The games were social and educational in nature because they aimed to prepare children and young people for life and introduce them to society as a full-fledged one, according to their age-specific abilities. They consistently became riders, hunters, warriors. In ancient society, physical culture elements permeated all aspects of social life. Moreover, physical culture during this period was blessed with various customs, traditions, ceremonies and rituals. Kyrgyz people are in a mountain environment due to their nomadic culture, and sports preserve many features of their identity. This is because in the peculiar conditions of the steppe and high mountains in constant struggle with the element of nature, militarized physical education always has a special importance. Additionally, for a long time the same natural conditions preserved a patriarchal and early feudal, militant lifestyle. The main features of the games and exercises aimed at training talented and brave warriors were that they were very harsh and very risky.

\subsection{Horse domestication and games}

Domesticating equestrian horses leads to the emergence of equestrian games and sports and competitions suitable for the purposes of military training. The emergence of "military democracy" at the stage of the disintegration of the primitive communal system - associated with the emergence of Alaman-Baigi in the Central Asian steppes - was a form of competition used to train a warrior. Countrywide, by contrast, traditional sports, games, and exercise are unique in many ways. The right goals, objectives, contents and development dynamics change depending on the needs of modern physical education of the population, and this process is undoubtedly accompanied by the increasing mutual enrichment of national cultures and the active formation of the international characteristics of man in modern society. Rojdestvenskiy made the first monographic study about Kyrgyz traditional sports in 1928. Studies carried out in the 19th century and the first half of the 20th century were mostly sub-titles. In 1980, Simakov made the best anthropological compilation of games. It is now recognized in anthropology that cultural analysis must somehow be contextualized within a historical framework (Cohn, 1987; Fabian, 1983; Rosaldo; Sahlins, 1995). This does not mean that ethnography should be based on reconstruction. History must be integrated into a holistic understanding of institutions and groups. It is not enough to reference the past without making a critical evaluation as much as the history of an event is an objective and unbiased definition and is a reflection of current concerns. Conversely, the reassessment of history can shed an important light on the way ethnography is interpreted and analyzed. The lack of historical information in this work prevents me from using history in this way. Because these two sources have a lot of repetition but little elaboration.

\subsection{Some thoughts on Kyrgyz sports history}

Sports history is never independent from general and cultural history. In the meantime, we had better not forget the terrible description of history by the Soviet regime for 70 years. This regime not only succeeded in inventing a history in accord with its doctrinal postulates. But at the same time, by dogmatizing the theories of Hegel and Marx, it was 
able to create the "infallible" method of the analysis of history and the extravagance of the fundamental contribution of historical materialism, an instrument of political doctrine that had to serve as the logical consequence of initially accepted compromises. T. Adorno wrote: "If we try to summarize the most prominent orientations of our culture, we cannot find a more productive field for this than sports today" (1982). He says that the way the game is consumed reveals all kinds of information about society and cultures, which is true. Turkish peoples created nearly 400 sports in accordance with the steppe lifestyle, especially Horse Riding, Shooting and Wrestling, according to their national will and qualities. It can be clearly seen that religious elements lie in the intellectual direction of their display and national elements in the direction of their shape (Türkmen, 2018). The Kyrgyz writer Anarkulov said, "People's will, wish, hope, joy, care, heroism, boldness and struggle towards freedom and equality, justice and truth were reflected in these games and essentially constituted the content of these games. The decent examples of the people, their deep philosophical views and the whole national character can be seen in these games" (1991, III).

For an outsider, understanding Kyrgyz traditional sports undoubtedly sheds a lot of light on other aspects of the social life of the Kyrgyz and even other Turkic peoples. There is no other sports in Kyrgyzstan that carries as much symbolic "weight" as the buzkashi game (gök-börü). The emotions evoked by Gök-Börü are far from static or law. The interpretations of the symbols and images of the Gök-börü can of course be used in different ways and can be adopted as tools in hegemonic processes and their opposing counterparts. In fact, the gök-börü is used systematically in the creation of myths and in moral education, in competitions and demonstrations, as in the western notion of chivalry. Traditional sports, especially horse riding, shooting and wrestling, are seen by the Kyrgyz as a way of honing vigilance and combat techniques, but they also see physical dexterity as a sign of spiritual strength and blessing. Finally, these sports show a deep interest in the importance of male power and an aesthetic code in which the "alpine male characteristic" reported by anthropologists in Central Asia is equated with physical dexterity (Türkmen, 2013).

\section{Conclusion and recommendations}

Asiatic nomad physical education tools and systematic formulation of physical education in Kyrgyz in the past are the conditions of militarized social life style. Although the Kyrgyz were a well-established Turkish tribe, they were small in population. For this reason, they were busy training strong, experienced warriors in the future. In military affairs, the children developed their arts by capturing the horse and actively participated in various competitions and martial arts. Kyrgyz national sports games and entertainment are an integral part of its cultural heritage. Physical culture and sports, as a product of certain historical conditions for the development of society, constitute the sum total of the historically occurring consequences of man's spiritual activity. Under the conditions of the nomadic lifestyle, Kyrgyz horse-riding sports games continued to remain the main forms of physical culture and the main tools of physical education, and among children, outdoor games - again reflecting their content - were determined to be 
natural products of a nomadic lifestyle. Specific ethnographic materials show the connection of the nomadic Kyrgyz sports exercises and games with their lives, a reflection of folk culture elements, life, rituals, magical beliefs. Such competitions were very popular and were held in free time from work - at weddings, funerals, memorials, memorable religious days, rites of the calendar cycle, etc. The Kyrgyzs were in a nomadic mountain environment, and sports still preserve many features of their identity. This is because in the peculiar conditions of the plains and high mountains in constant struggle with the element of nature, militarized physical education always has a special importance. Furthermore, the same natural conditions for a long time arise from the fact that they preserve a patriarchal and early feudal, militant way of life as a necessity for his economic life.

A society that had to constantly search for pasture for its animals could enter into conflict with another tribe at any moment. However, the low population led to the emergence of games and exercises aimed at training talented and brave warriors in Kyrgyz, that is, the nomadic lifestyle revealed the demand for such games by nature. Thus, the Kyrgyz wrote their own name in history as a soldier and riding people. On the other hand, the ancient and widespread sports that Kyrgyz did in the classical period and Central Asia, and the authentic extensions of these sports that have survived until today constitute one of the focal points of the social sciences. The prejudice of only two researchers in the Soviet era that "games appealed to the most primitive motives of the Kyrgyz" with the rush to join the regime individually led them to stay away from these sports studies for a while. However, the popularity of the games again showed that they intensified the interest of social researchers. In the exhibition of Kyrgyz national games, sources from the 19th and early 20th centuries testify to the existence of archaic features of pre-Islamic culture within the framework of naive and food, as well as ethnographic reality. Thus, it can be said that whichever way you think about it, we cannot escape the conclusion that although Kyrgyz traditional games develop warrior skills in their historical or psychological, subjective or objective origin, they have a religious side and are spiritual in nature, at least as old as recorded history.

\subsection{Recommendations}

Physical culture is one of the historically formed parts of national culture and is also one of the most important tools for educating a person. Consequently, it is recommended that the development of human culture, including physical culture as part of the general culture of the people, should be more seriously studied to make it an important business throughout Kyrgyzstan. Furthermore, it should not be forgotten that Kyrgyz indigenous writers have a homogeneous cultural structure with all the peoples of Central Asia (Turkistan), especially Kazakhstan, and that they are a product of national culture in traditional games and sports, so it is recommended that they act with the consciousness of being the same nation, not with a tribal understanding.

\section{Conflict of interest statement}

There are no potential conflicts of interest on this article. 


\section{About the Authors}

Mehmet Turkmen is Professor Doctor at Muş Alparslan University, Turkey and KyrgyzTurkish Manas University, Kyrgyzstan. His research interests are physical education, sport and sport history.

\section{References}

Adorno, Theodor (1982). Prisms. Cambridge, Massachusetts: MIT Press

Anarkulov, H. F. (1991). Kırgızdın El Oyundarı. Bişkek: Nauk.

Bartold, V. V. (1996) Selected Works on the History of Kyrgyz and Kyrgyzstan. Bishkek, Nauk.

Cohn, B. S. (1987). An Anthropologist Among the Historians and Other Essays. Delhi: Oxford Univ. Press

Elias, Norbert (1939). Über den Prozeß der Zivilisation. V. 1, Basiléia: Verlag Haus zum Falken.

Elashvili, V. I. (1973). Traditsii gruzinskoy narodnoy fizicheskoy kul'tury i sovremennost, Tiflis: Metsniyereba.

Fabian J. (1983). Time and the Other: How Anthropology Makes Its Object. New York: Columbia Univ. Press.

Jung, C. G. (2007), Insan ve Sembolleri. Çev.: A.N. Babaoğlu, İstanbul: Okuyanus Yayınevi.

Khamchiyev, K. M. ZH. K. Bukanova, ZH.K. Karimova, G.T. Il'yasova, L.V. Kirilinskaya. (2013). Razvitiye natsional'nykh vidov sporta i narodnykh igr. Astana: TOO «Shikula i K». - 40 s. na russkom yazyke.

Lavega, P. (2007). Traditional games in Spain. A Social School of values and learning. in: International Journal of Eastern Sports E Physical Education (IJESPE). vol. 5, 1 p. 152170.

Mendot, E. E. - A. V. Gaskov, A. A. Sakhiulin (2014). Development of physical culture and sport in Tuva. Vestnik Buryatskogo Gosudarstvennogo Universiteta, 13, pp. 128132.

Parlebas, P. (2005). El joc, emblema d'una cultura, Enciclopedia Catalana “Jocs i Esports tradicionals". Tradicionari, Enciclopèdia de la cultura popular de Catalunya, Vol. 3 Barcelona: Enciclopèdia catalana; s.13-20.

Rojdestvenskiy, P. A. (1928). Kırgiziskiye natsionalnıye sport igri. Frunze.

Rosaldo, R. (1994). Whose cultural studies?, Anthropology, 96: 524-29 pp.

Sahlins, M. (1995). How "natives" think. About Captain Cook, for example. Chicago: Univ. Chicago Press

Simakov, G. N. (1980). Obshhestvennye funkcii kirgizskih narodnyh razvlechenij v konce XIX v. - nachale XX v. Leningrad: Nauk.

Taysayev, K. U. (1997). Etnografiya traditsionnogo sporta u narodov Severnogo Kavkaza. Academic degree: Doctor of Historical Sciences Place of defense of the thesis: Moscow, VAK specialty code: 07.00.07

Türkmen, M. (2013). Opinios about Kirgiz traditional equestrian sports. Vestnik Fiziçeskoy Kulturi i Sporta, Volume (İssue) No: 1- (9): 74-79. 
Türkmen M. İmamoğlu, O. Ziyagil M. A. (2006). Popularity of the Wrestling sport in Turkey and it's comparison with the selected sports. Researches About The Turks All Around The World,163: s. 77-94.

Türkmen, M. \& Ziyagil M.A. (2020). Kırgızistan ve Türkiye'de Geleneksel Atlı Sporlarına Yönelik Bilgi Kaynağı, Tutum, Katılım ve Tercihlerin Karşılaştırılması, 9th International Turkish Folks Traditional Sports Games Symposium, 29-30 November, Bishkek/ Kyrgyzistan, 2020, 39-51 pp.

Türkmen M. \& Arstanbekov S. (2020). Kazakh Traditional Wrestling with its Formation and Transformation Aspects: Kyres (Küres). European Journal of Physical Education and Sport Science, ISSN: 2501-1235, 6-(8): 91-103. 

be applied to their work. Under the terms of this license, no permission is required from the author(s) or publisher for members of the community to copy, distribute, transmit or adapt the article content, providing a proper, prominent and unambiguous attribution to the authors in a manner that makes clear that the materials are being reused under permission of a Creative Commons License. Views, opinions and conclusions expressed in this research article are views, opinions and conclusions of the author(s). Open Access Publishing Group and European Journal of Physical Education and Sport Science shall not be responsible or answerable for any loss, damage or liability caused in relation to/arising out of conflict of interests, copyright violations and inappropriate or inaccurate use of any kind content related or integrated on the research work. All the published works are meeting the Open Access Publishing requirements and can be freely accessed, shared, modified, distributed and used in educational, commercial and non-commercial purposes under a Creative Commons attribution 4.0 International License (CC BY 4.0). 